Another Sleeping Beauty: Narcissism in The House of Mirth

Author(s): Joan Lidoff

Source: American Quarterly, Vol. 32, No. 5 (Winter, 1980), pp. 519-539

Published by: The Johns Hopkins University Press

Stable URL: http://www.jstor.org/stable/2712411

Accessed: 11-05-2015 20:25 UTC

Your use of the JSTOR archive indicates your acceptance of the Terms \& Conditions of Use, available at http://www.jstor.org/page/ info/about/policies/terms.jsp

JSTOR is a not-for-profit service that helps scholars, researchers, and students discover, use, and build upon a wide range of content in a trusted digital archive. We use information technology and tools to increase productivity and facilitate new forms of scholarship. For more information about JSTOR, please contact support@jstor.org. 


\title{
ANOTHER SLEEPING BEAUTY: NARCISSISM IN THE HOUSE OF MIRTH
}

\author{
JOAN LIDOFF \\ University of Texas at Austin
}

DESPITE THE PRESENT RENEWAL OF INTEREST IN The House of Mirth, reminiscent of the enthusiasm that greeted its publication in 1905, criticism has not yet explained the single most powerful aspect of the novel: the extraordinary appeal of its heroine, Lily Bart. Lily somehow exceeds the bounds of critical definition as she does the intentions of Edith Wharton's narrative structure. She is one of the most compelling of the female spirits-Emma Bovary, Anna Karenina, Maggie Tulliver, Edna Pontellier - struggling to forge their own destinies, whom, as Diana Trilling points out, literary convention customarily destroys. ${ }^{1}$ Critics have recognized the super-added energy of The House of Mirth ${ }^{2}$ and acknowledged Lily's "mysterious appeal.",3 "Lily Bart is by far the most vivid of Mrs. Wharton's heroines," writes Louis Auchincloss." "Simply as an example of imaginative portraiture," Irving Howe proclaims, she is "one of the triumphs of American writing.", 5

To Edith Wharton, Lily is an inevitable victim of destruction by social institutions' collective necessities. Wharton's declared intent was to il-

${ }^{1}$ Diana Trilling, "The Liberated Heroine," Times Literary Supplement, 13 (Oct. 1978), $1163-67$.

${ }^{2}$ Patricia Spacks, The Female Imagination (New York: Knopf, 1975). She writes, "The House of Mirth has the energy of a parable" (241). Gary Lindberg detects in Lily "psychic energies that are unmalleable to social forms." See Lindberg, Edith Wharton and the Novel of Manners (Charlottesville: Univ. Press of Virginia, 1975), 122.

${ }^{3}$ R. W. B. Lewis, ed., The House of Mirth (New York: New York Univ. Press, 1977), vi. This is the text of Wharton's novel used here. All page numbers, indicated in parentheses after quotations from The House of Mirth, are to this edition.

${ }^{4}$ Wharton, The House of Mirth (New York: New American Library, 1964), Afterword, 343.

${ }^{5}$ Irving Howe, ed., Edith Wharton: A Collection of Critical Essays (Englewood Cliffs, N. J.: Prentice-Hall, 1962), 125. 
luminate the tragic possibilities of the idle society of the wealthy by showing what that society destroys. ${ }^{6}$ Lily is "a captured dryad subdued to the conventions of the drawing room" (11), conquered by the constant tension between social discipline and the spontaneous feeling of individual impulse. Yet she rises out of the sea foam of this deterministic world with a power that far exceeds her role as a pawn of hostile social forces. Writes Irving Howe, "before the pathos of her failure, judgment fades into love, ${ }^{7}{ }^{7}$ and readers do regularly fall in love with Lily. Lily charms the reader as she does the other characters in the novel (and as she has her creator). We are bewitched by the beauty of her grace and vitality of spirit as well as her appearance. Irrationally, we wish with her for a prince to transport her from her troubled poverty to the paradise of wealth and security she craves; we concur in her yearning to live happily ever after.

These fairy-tale expectations are generated by the emotional structure of the plot; they are thwarted by that same structure. Lily dies at the novel's end, destroyed by the tyranny of social manners; but she is first the victim of the limitations of Wharton's fictive world. Richard Chase has declared that "whenever it turns out to be a brilliant and memorable book, the American novel of manners will also be a romance." 8 The House of Mirth, I wish to argue, is primarily a romance of identity. Though it purports to be a novel of social realism (which Gary Lindberg convincingly places in the tradition of the novel of manners), it is controlled by a deeper underlying dynamic. Before the society the novel portrays makes life impossible for Lily, the novel's structure itself forbids the realization the character and plot seek. At the same time, Lily derives

\footnotetext{
${ }^{6}$ In A Backward Glance Wharton writes of The House of Mirth: "The problem . . . how to extract from such a subject . . . a society of irresponsible pleasure seekers . . . any deeper bearing than the people composing such a society could guess? The answer was that a frivolous society can acquire dramatic significance only through what its frivolity destroys. Its tragic implication lies in its power of debasing people and ideals. The answer, in short, was my heroine, Lily Bart" (207). Wharton here establishes a confusion between tragedy and determinism that plagues criticism of the novel in an unresolved debate about Lily's stature as a tragic heroine. All of Wharton's characters live in an essentially deterministic universe. Without a modicum of free will and interior spirit the moral responsibility necessary for tragedy is hardly possible. Yet the feeling that Lily is a tragic character keeps re-emerging. In both Irving Howe's and Edmund Wilson's criticism, the dimensions of tragedy and determinism seem paradoxically to coexist. Cf. Howe, ed., Edith Wharton, and Wilson, "Justice to Edith Wharton" (1941) in The Wound and the Bow (New York: Oxford Univ. Press, 1947). But R. W. B. Lewis states blankly that Lily "is not a tragic heroine" (xx) and Wharton's most reliable early critic, Blake Nevius, writes, "we are deceiving ourselves if we try to account for the compelling interest of The House of Mirth by the nature or intensity of the moral conflict." See Nevius, Edith Wharton: A Study of Her Fiction (Berkeley: Univ. of California Press, 1953).

${ }^{7}$ Howe, ed., Edith Wharton, 127.

${ }^{8}$ Richard Chase, The American Novel and Its Tradition (New York: Doubleday, 1957), 160 .
} 
her extraordinary appeal from the nexus of primordial feelings the romance taps.

Traditionally, the romance form makes its external world out of its hero's inner world. ${ }^{9}$ It populates a hero's journey of self-discovery with token figures representing aspects of himself which he must learn to confront and accept. Reading The House of Mirth as a romance, we see the conflicts Lily encounters as internal: the other characters appear as aspects of her own needs and feelings. Her fate measures the success with which she resolves, or fails to resolve, these developmental conflicts.

The romance form generally permits resolution: an ending in which the hero reclaims the divided aspects of himself in a new personal and societal integration. Women's heroic journeys often end in failure because society offers women no adequate forms of active adulthood. When reality thwarts the forward progress of maturation by perpetuating childlike passivity in adult roles, dissonances are felt subtly within the female psyche. Lily is unable to move towards integration; she remains locked in the regressive emotional state of primary narcissism, which in turn mirrors her fictive world. This early developmental stage is characterized by a fusion of one's feelings and desires with the outside world. Difficult aspects of the self are projected onto others so that rather than becoming coherent and realistic, the self-concept remains idealized. In this initial mechanism of projection, romance and narcissism are alike; however, while romance allows for recognition and thus reintegration, narcissism prohibits this self-knowledge.

In narcissism, the distinction between fantasy and reality is not clear. Similarly, Wharton's fiction confounds realism with romance. Failing to clarify the difference between the social world and the psychological, her novel does not stay consistently within either framework, but tries to resolve issues from one dimension in terms of the other. What purports in her plot to be a mimetic description of the social world is often unconvincing as realism: a persistent inability to acknowledge aggressive drives (consistent with cultural images of femininity) results in a confusion within Wharton's narrative framework of the dynamics of moral causality with the psychological determinism of fantasy. Wharton provides many cues which encourage reading her novel of social realism as a romance. Lily's allegorical progress from house to house down the social scale invites us to read in romance's allegorizing, abstracting mode, as do the symbolically suggestive names: Lily and Rosedale, Bellomont, Stepney. Like the typical romance hero(ine), Lily is

${ }^{9}$ See Joseph Campbell, The Hero with a Thousand Faces (1949; rpt. Princeton: Princeton Univ. Press, Bollingen Series 17, 1968) and Northrup Frye, Anatomy of Criticism (Princeton: Princeton Univ. Press, 1957). 
an orphan, powerless and alone in her quest for identity. None of the secondary figures are real Others with whom it would be possible for her to have a significant relationship. Silent spaces between characters remain unbridgeable because the characters themselves are the simplistic projections of unintegrated fragments of personality. Paradoxically, Wharton's fiction operates from a narcissistic fantasy of ecstatic oneness, while it creates a world in which communion is impossible and isolation inevitable.

In his introduction to the Gotham Library edition of The House of Mirth, R. W. B. Lewis notes that the drama in the human encounters in this novel is unrealized-artfully, he says, suppressed. But it is the drama of the novel as a whole that is inadequately realized. Emotional connections are not made, feelings and events are stopped short of completion. Lily is another Sleeping Beauty, slumbering in a dormant presexual state from which she never awakens. ${ }^{10}$ Wharton's narrative not only portrays this state, but itself suffers the same frustrations. A dynamic of repression animates, and de-animates, this fiction. The first book of The House of Mirth is consistently powerful; the scenes in Book II set up to mirror scenes of emotional force in Book I are, however, frequently inadequate. Lily's charged walk with Selden at Bellomont is reflected structurally by another walk with Rosedale which lacks all of the color and appeal of the first. Her visit to the working girl Nettie Struther and her infant, and the death scene that concludes the novel, are both stock sentimental pieces substituted for scenes of emotional climax or resolution. Even before the limitations of Lily's character doom her, she is damned to destruction by the constrictive walls of the inhibited psychic world from which Wharton has constructed her novel. This is the real locus of the determinism of Wharton's fiction, in which the consequences of social inhibitions are felt.

Simultaneously, however, Lily derives her potency as a character from the very emotional configuration which dooms her. In her later, more perfectly structured novel, The Age of Innocence, Wharton controls in a more balanced way the feelings she releases with Lily Bart; but no single character in that novel has quite Lily's appeal. Wharton's language most clearly reveals the potent emotional sources from which Lily is drawn. Lily is described by a consistent pattern of metaphors of unrestrained gratification and sensual delight that belong to the universal fantasy of Eden and appeal with the force of lost paradise.

${ }^{10}$ Elizabeth Ammons, in "'Fairy-Tale Love' and The Reef' American Literature, 47 (1975), 615-28, observes a similar use of fairy-tale motifs to expose female fantasies about love and marriage generated by cultural limitations encouraging economic dependence and sexual repression. 
Wharton surrounds Lily with the libidinal imagery of wish fulfillment. She is presented to us cushioned in pleasure: "Her whole being dialated in an atmosphere of luxury; it was the background she required, the only climate she could breathe in" (23). Having a totally sustaining environment, where "everything in her surroundings ministered to feelings of ease and amenity" (37), is not a luxury for Lily but a necessity. Her life is nourished, like an infant's, by an amniotic bath of sensual satisfactions. Her images are fluid: "She was like a water-plant in the flux of the tides, and today the whole current of her mood was carrying her toward Lawrence Selden" (51). With Selden, "the horizon expanded, the air grew stronger, the free spirit quivered for flight ..." and a "sense of buoyancy ... seemed to lift and swing her above the sun-suffused world at her feet" (62). Lily's characteristic motion is the graceful swing of free flight; she lives not in an earthbound world of gravity, but in an unbounded fantasy world, free from the weight of cause and effect. The verbs which regularly describe her are: "glow," "throb," "dialate," "dazzle," "kindle," "shine," "delight," "quiver," "swing," "soar," “flow,", "thrill”expressions of quick sensual response, of energy that admits of no channeling. Lily is " buoyant," "charming," "radiant," "vivid," "intoxicating," "delicious," "elegant," "clear," "exhilarating"; this is the aura of her presence. Being wealthy is another metaphor for this safe and harmonious life of perfect and effortless pleasure. Marrying money, Lily assumes, would let her "soar into that empyrean of security [where] she would be free forever from the shifts, the expedients, the humiliations of the relatively poor" (47). In this world of wealth, sunlight "caresses" the furniture, rooms afford a view of "free undulations of a park" (37). In this Eden, one's beauty is sufficient magic to make all one's desires automatically materialize. And Lily is beautiful.

Wharton repeatedly uses chiaroscuro lighting to illuminate Lily's beauty dramatically against the background of drabness (moral and physical) of the other women around her. Lily feels that "the dinginess of her present life threw into enchanting relief the existence to which she felt herself entitled"' (32). The first view we have of Lily is through Selden's eyes; he sees her among the throngs at the train station and wonders, "Was it possible that she belonged to the same race? The dinginess, the crudity of this average section of womanhood made him feel how highly specialized she was" (3). (Seldon too has features that "[give] him the air of belonging to a more specialized race.") Lily explicitly articulates the perception that she is "a creature of a different race . . . with all sorts of intuitions, sensations and perceptions that [others] don't even guess the existence of"' (46). 
Lily is persistently characterized by this metaphor of specialness: she sits, stands, and walks apart from others. The special race to which Wharton makes Lily and Selden belong is that of the fairy-tale royalty of Freud's family romance, a fantasy generally outgrown, or suppressed, with childhood. Freud describes the typical childhood notion that one is a changeling, the offspring of royal parents mistakenly placed among commoners but in truth exalted above them. This fantasy is an attempt to preserve the narcissistic image of perfection in the face of inevitable disappointments. ${ }^{11}$ The dark underside of this glorification is the instability formed of the child's fears and feelings of powerlessness.

Similarly, beneath the metaphors of beauty and specialness runs another strain of Lily language. Holistic and absolute, Lily's moods swing between the intoxicating rush of triumphant excitement and dull despair. The brilliance and intensity of her highs is predicated on the bleak emptiness of her lows. Beneath the free air where her spirit quivers, expands, and swings buoyantly (62) is a "prison-house of fears" (61). When things go wrong, she feels not moderate disappointment or frustration, but a deep self-disgust. Never seen as a competent, adult woman, Lily is regarded as a commodity, a beautiful object of art, ${ }^{12}$ but she is also often imaged as a troubled, helpless child, "longing for shelter, for escape from . . . humiliating contingencies" (94). Lurking under the imagery of sensual gratification is a second language of intense, ungratifiable neediness and fear, of a tenacious hunger for comfort and security.

Lily's encounters with Selden elicit from her both extremes of feelings. In the splendid scene at Bellomont, the luxurious country house where they are guests, Lily walks through the gardens and woods to sink into a rustic seat in a set romantic scene. She knows the charm of the spot is enhanced by the charm of her presence, "but she was not accustomed to taste the joys of solitude except in company" (58). She wilts: "She felt a stealing sense of fatigue as she walked; the sparkle had died out of her, and the taste of life was stale on her lips. She hardly knew what she had been seeking, or why the failure to find it had so blotted the light from her sky: she was only aware of a vague sense of failure, of an inner isolation deeper than the loneliness about her" (58). When Selden appears, she

${ }^{11}$ See Sigmund Freud, "Family Romances," in James Strachey, ed. and trans., The Standard Edition of the Complete Psychological Works of Sigmund Freud (London: Hogarth Press, 1955), 9:1906-08.

${ }^{12}$ Cynthia Griffin Wolff's reading of The House of Mirth in "Lily Bart and the Beautiful Death," American Literature, 46 (1974), 16-40, elaborates this perception of Lily as an object of art. "The death of a beautiful woman as seen through the eyes of her lover" was a set piece of American literature. Wharton, however, shows us "what it would be like to be the woman thus exalted and objectified," revealing "the self-alienation that a woman suffers when she accepts the status of idealized object" (39). 
instantly bubbles back into the luxury of enjoyment and gaiety that comes with their meetings. The fluid joy of unspoken communication between them brings a feeling of oceanic oneness; but it is in fact extremely fragile. With any disagreement, "the flow of comprehension between them was abruptly stayed." "It was as if the eager current of her being had been checked by a sudden obstacle which drove it back upon itself. She looked at him helplessly, like a hurt or frightened child: this real self of hers, which he had the faculty of drawing out of the depths, was so little accustomed to go alone" (92).

The fragility of Lily's self-image becomes increasingly apparent. Like a "sea anemone torn from [its] rock" (295) she is unable to exist alone. The first book ends with a statement that quakes with unintended irony: "It would take the glow of passion to weld together the shattered fragments of her self-esteem" (171). Lily's glow feeds on the absence rather than the abundance of internally animating energies; the intensity of her intoxication manifests her dependence on others for all of her self-esteem. Isolation is terrifying to her: her whole sense of being requires another's presence. Yet she is prohibited by her own emotional structure, and that of the novel she inhabits, from any possibility of receiving from or giving to others. She appears lovely, a fantasy of perfection. But coexisting with this idealized self is another, characterized by a deep void of deficient confidence and stability. As the glowing Edenic imagery of the first book fades, the novel's second book is progressively dominated by language of deprivation, anxiety, resentment and fear. The persecution and disintegration that Lily experiences in the plot are not unrelated to her loveliness; they are intrinsic to it. As her charm plays out the graces of narcissistic pleasures, so her fall from social grace, her progressive isolation, and her victimization by vengeful characters who have the power she does not to initiate action enact the underside of the narcissistic fantasy.

The term "narcissism" is now in vogue in the currency of social criticism. As a psychoanalytic concept, it is undergoing reformulation at the hands of Heinz Kohut and Otto Kernberg. ${ }^{13}$ I mean it here neither in

${ }^{13}$ See Heinz Kohut, The Analysis of Self (New York: International Universities Press, 1971); "Forms and Transformations of Narcissism," Journal of the American Psychoanalytic Association, 14 (1966), 243-72; Otto Kernberg, "Contrasting Viewpoints Regarding the Nature and Psychoanalytic Treatment of Narcissistic Personalities: A Preliminary Communication," Journal of the American Psychoanalytic Association, 22 (1974). This issue is entirely devoted to discussions of narcissism. Also see Marion Michel Oliner, "Le Narcissisme: Theoretical Formulations of Bela Brumberger," The Psychoanalytic Review, 65 (Summer 1978). 
the diluted common usage as "self-love" nor in the clinical sense as a specific pathological personality structure. While narcissism is dysfunctional as an overall personality defense, Kohut elaborates Freud's formulation to argue that the infant's universally shared primary narcissism can be perpetuated in adults as one in a repertory of responses, a residue we retain from the infant's initial feeling of oneness with the mother. Lily partakes both of its appeals and its dysfunctions. Derived from the intense, instinctual level of experience, the narcissistic state is wedded to libidinal energy and sensual pleasure. A striving to return to the elation of this oceanic fusion informs mythologies of Paradise and symbols of Eden's garden. Its sensuality and illusion of oneness exercise continuing appeal in sexuality and in mythologies of romantic love.

The libidinal imagery that defines Lily and her sense of specialness are those of the infant's Eden; the fantasy she speaks to of eternal power, wealth, youth, and beauty derives from this paradise free from both work and mortality. Originally, the infant experiences all his needs as being gratified instantaneously and completely by the nurturing mother, whom he perceives as an extension of his own being. Believing his needs and desires to be congruent with the external world, the infant does not feel the necessity of producing effects by generating causes, of earning his own satisfactions. Wishes, not actions, motivate his world. The expectation of automatic fulfillment and delight translates into a sense of specialness, of exemption from the laws of causality that govern others' fates.

The habit of perception characteristic of infant narcissism is called "primary process thinking." For sequential, linear causality, it substitutes symbolism and holistic magic. Monolithic, this world view does not allow the possibility of change or development; everything seems absolute, permanent. All perceptions are rigidly polarized-black or white, on or off, with no tolerance for ambiguity or doubt. The emotional affects of narcissism are either elation or despair, without modulation.

This polarization is absolute because the narcissistic state precedes the development of initiative or assertion; narcissistic thinking cannot acknowledge drives-the wish to act autonomously to attain one's desires, or the capacity to do so. While narcissism presumes magical security and gratification, it in fact entails vulnerable and passive dependence on the generalized environment to provide satisfaction. Its idealized self-image of omnipotence and perfection is preserved only by projecting aggressive feelings onto others, whose helpless, innocent victim the narcissist then becomes. Otto Kernberg explains the need to cling to the narcissistic self-concept: "To accept the breakdown of the illusion of grandiosity means to accept the dangerous lingering awareness of the depreciated self-the hungry, empty, lonely primitive self surrounded by a world of 
dangerous, sadistically frustrating and revengeful objects." ${ }^{14}$ Kernberg's description of narcissistic dynamics summarizes the latter half of The House of Mirth.

In Wharton's fiction, as in narcissistic thought, characters and alternative actions frequently are presented as black or white, good or bad. There are no possibilities of compromise or moderate resolution. This fictive world suggests the romance realm of fairy tales, wherein as Bruno Bettleheim explains, such polarization and externalization of fantasy can be used to work developmental conflicts through to resolution. ${ }^{15}$ The House of Mirth is sprinkled with fairy-tale allusions. Wharton often uses the language of fairy-tale magic for Lily, and gives her magical powers. She has a Prince Charming in Selden, a frog prince in Gus Trenor, a wicked stepmother in Bertha Dorset, and an evil stepsister in Grace Stepney. Lily herself plays Sleeping Beauty, though one who fails at her initiation rites of awakening (as she is failed by those who should help her in those tasks). Wharton appears to be writing an adult version of the stories which, in her childhood, were too frightening for her to face. She writes, in A Backward Glance, "I never cared much in my little-childhood for fairy tales, or any appeals to my fancy through the fabulous . . my imagination lay there, coiled and sleeping, a mute hibernating creature." "Fairy tales bored me," she declares. ${ }^{16}$ Cynthia Griffin Wolff's biography of Wharton suggests that this boredom was in fact a defense; that as a child, Wharton was "made acutely uncomfortable by their primitive emotional directness." When writing gave Wharton the tools to begin to reexamine feelings that were overwhelming to her when she was young, she was able to return to those emotional depths, and began to write her own fairy tales-in the form of romance.

Lily's appeal testifies to the success with which Wharton was able to free the rich resonances of early narcissistic longing and the elation of wish fulfillment. At the same time, Wharton maintained some of her earlier ambivalence about acknowledging these emotions, manifested in the novel's unsettled combination of realism and romance. The novel is uneasily cast in a satiric mode, a rigid protective style of distancing emotion by rational and verbal artifice. But Wharton's various strategies of narrative control are only partially successful, their fragility belied by the way feeling repeatedly breaks through. When Lily is pressed by Judy Trenor

${ }^{14}$ Kernberg, "Contrasting Viewpoints," 265-66.

${ }^{15}$ Bettleheim, The Uses of Enchantment: The Meaning and Importance of Fairy Tales (New York: Random House, 1977).

${ }^{16}$ Edith Wharton, A Backward Glance (New York: D. Appleton-Century, 1934), 4. Quoted in Cynthia Griffin Wolff, A Feast of Words: The Triumph of Edith Wharton (New York: Oxford Univ. Press, 1977). 
to participate in the nightly gambling at Bellomont, she is afraid to get involved. Like Pope's "The Rape of the Lock," this card game proceeds on a level of sexual double entendre. Lily fears "the gambling passion" that overtakes her. She "knew she could not afford it" (24). Once caught up in its exhilaration, her spending and repentance are both profligate. Lily has realized that "the luxury of others was not what she wanted." Beginning "to feel herself a mere pensioner on the splendour which had once seemed to belong to her," she is becoming "conscious of having to pay her way" (23). But the ambivalent activity of gambling is the only form of adult responsibility available to Lily. For both Lily and the novel itself, when feeling is released, it does run out of control, because there are no realistic channels to shape it.

Wharton casts this story, dominated by emotional issues, into social and financial terms. Both characters and narrator persistently confound the language of love and money: love is spoken of in terms of cost, expense, value, while the stock market is discussed in the language of dependence and independence, betrayal, suffering, and sympathetic affection (cf. 117). Wharton's intent in this metaphorical interchange of love and money is sometimes patently satiric, but it is not always clear that she is controlling, rather than controlled by, the substitution. "The underflow of a perpetual need" that tugs at Lily's family is as much a need of emotional security as it is "the need of more money" as Wharton declares. This metaphoric confusion reflects the narrative's inconsistent intermingling of romance with realism.

Wharton's attitude towards her heroine is similarly inconsistent. Although, like Selden, she tries to make Lily a satiric object, Lily's charm exceeds the confinement of that characterization; Wharton's deepest sympathies are aroused by her heroine. At the same time, her punitive assessment of Lily is harsh in the extreme, taking its ultimate form in Lily's death. The judgmental dichotomizing in Wharton's thinking prevents her beautiful child from becoming a heroine as much as do the real constrictions in Lily's social world that prohibit her from overcoming her childishness.

Polarizing characters and action with the absolutism of primary process fantasy, Wharton establishes impossible alternatives for her heroine; Gerty Farish, especially, is used blatantly "to throw [Lily's] exceptionalness into becoming relief" (86). "Fatally poor and dingy" (86), Gerty provides a dim background against which Lily glows. They are set up as diametrical opposites. Gerty's "eyes were of a workaday grey and her lips without haunting curves" (86). Her gown is of a "useful" color, her hat has "subdued lines" (86). Lily finds "something irritating in her assumption that existence yielded no higher pleasures" (86); and indeed, Gerty is 
as excessive in her expectation of too little pleasure from life as Lily is in hers of too much. When Lily considers whether she should marry Percy Gryce, she sees only two choices for herself: "It was a hateful fate-but how to escape from it? What choices had she? To be herself, or a Gerty Farish." To be Gerty means to live in an environment "cramped," "cheap," "hideous," "mean," "shabby," "squalid," while Lily enjoys one of total luxury, beauty and charm, of softly shaded lights, lace, silk, embroidery, perfume (23).

In her conception of Gerty and Lily, Wharton makes a complete and exclusive dichotomy of pleasure and usefulness: Lily's mode is all pleasure, Gerty's all use. There is no connection, for character or narrator, between cause and effect, activity and gratification, work and pleasure. Wharton describes Lily's family life as alternating between "grey interludes of economy and brilliant reactions of expense" (26). The passive expectation of swinging between extremes is all that is available to Lily, who is inhibited from action by thinking she has only two rigidly conceived and equally unsatisfactory choices. This all-or-nothing thinking is immature, but within the terms of the novel, it is realistic. Wharton gives Lily only the two radical alternatives (or non-alternatives) she perceives for herself.

The one instrument with which Wharton allows Lily to initiate action works only by holistic magic. The source of Lily's power to move others is felt to be her beauty, which is conceived as a Platonic ideal, not an expression of adult sexuality. To look on Lily's "loveliness was to see in it a natural force, to recognize that love and power belong to such as Lily", (162). Selden considers Lily's beauty a part of "that eternal harmony" (131) and Lily herself believes it part of "her power, and her general fitness to attract a brilliant destiny" (85). (Her mother has trained her to feel that she can give her beauty "a kind of permanence" and use it to win her fortune.) Wharton shares this fantasy of beauty's permanence and power; at the end, she will preserve Lily for us by her death, forever beautiful, forever young.

In one of the novel's key scenes, the tableau vivante in which Lily displays herself, literally, as an art object, Wharton shows that Lily does have some of the transforming powers she believes she has. The tableau scene is set to give us "magic glimpses" into "the boundary world between fact and imagination" (130). With Selden we "yield to vision-making influences as completely as a child to the spell of a fairytale" (130), and give ourselves to "the desire to luxuriate a moment in the sense of complete surrender" (132). Lily's audience reacts to her beautiful selfpresentation with a "unanimous 'Oh", (131), in an undifferentiated collective spirit whose warm bath makes her joyful. She is pleased to find 
herself the center of a "general stream of admiring looks" (133). "The individual comments on her success were a delightful prolongation of the collective applause. ... Differences of personality were merged in a warm atmosphere of praise, in which her beauty expanded like a flower in sunlight"' (133).

Lily evokes from others the response of preautonomous oceanic pleasure in which she thrives. "The completeness of her triumph gave her an intoxicating sense of recovered power" (133). While Lily's elation, the excitement of a successful performer after charming an audience, is credible, it is also illusory; she mistakes the confection of general admiration for substantial emotional sustenance. Her pleasure stands in ironic and inverse proportion to her real isolation. Loved by everyone in general, she is loved by and loves no one in particular. The autointoxication of this scene is the drunkenness of displaced sexual attraction but, significantly, its pleasures remain non-specific and non-sexual. Both her audience's responses and her own are global and diffuse, not active but passive, not other-oriented but incorporative, oral without being genital.

Lily's, and Wharton's, choice of Lawrence Selden as a love object is a primary manifestation of the confusion of passive with active modalities. Wharton suggests that Lily and Selden are possible lovers, but like Selden's "Republic of the Spirit," their love has no material base. That both they and Wharton believe it might leads to Lily's destruction. Selden is the one character who elicits Lily's romantic longings. Yet in Lily's relationship with Selden, Wharton dramatizes most concretely Lily's inevitable isolation. When Lily charms Percy Gryce on a train, miraculously making materialize for him a little table of delicacies, and bewitching him into eloquence, Wharton satirizes the fairy-tale scene she sets up, and the magical powers with which she endows her heroine ${ }^{17}$ But in Lily's scenes with Selden, Wharton herself concedes to the romanticism. They meet in paradisal atmospheres, imbued with the sensual color and protected security of the Edenic fantasy, but also with its comcomitant passivity. On a hill looking down on Bellomont, "the soft isolation of the falling day enveloped them: they seemed lifted into a finer air. All the exquisite influences of the hour trembled in their veins, and drew them to each other as the loosened leaves were drawn to earth" (70). Characteristically, they "stay silent while something throbbed between them in the

\footnotetext{
${ }^{17}$ Wharton's language in this scene is explicitly that of fairy tales and narcissistic fantasies: "With the ease that seemed to attend the fulfilment of all her wishes," Lily makes the tea table materialize. Gryce sees this feat as "miraculous"; the tea becomes "nectar," though Lily is reluctant to taste it, still savoring the "flavor" of another prince's kiss. Lily's effect on Gryce is magical: he "grew eloquent," feeling "the confused titillation with which the lower organisms welcome the gratification of their needs, and all his senses floundered in a vague well-being"' (18-19).
} 
wide quiet of the air"; "neither seemed to speak deliberately . . . an indwelling voice in each called to the other across unsounded depths of feeling" (64). For Lily and Selden, silences remain unbreakable; there is never any possibility of completed intercourse-verbal or physical-between them. Invariably, their encounters culminate in frustration, not climax; the novel itself concludes with a silence made permanent by Lily's death. Scenes between Lily and Selden operate with the intensity of suppression; they remain frozen in magical expectations without pragmatic means of realization.

The limitations of this characteristic imagery of hazy softness, miracle and magic are immediately apparent in their inappropriateness to practical financial dealings. While the need for money to sustain life is a social reality of utmost immediacy, Lily's attitudes towards money manifest her expectation that the material world should operate as fantasy does. She thinks about money in the language of magic: she is upset when she cannot "conjure back" a "vanished three hundred dollars" (25). Needing cash, she goes to Gus Trenor "with the trustfulness of a child." "Through the general blur her hopes dilated like lamps in a fog. She understood only that her modest investments were to be mysteriously multiplied without risk to herself; and the assurance that this miracle would take place in a short time, that there would be no tedious interval for suspense and reaction, relieved her. .." (82).

When Gus Trenor lures Lily to his deserted townhouse, his attempt to use his financial and physical power to coerce her sexually makes explicit the real connections between money, power, and sex that Lily has purposefully kept from her awareness. But the language and imagery Wharton uses in this scene show her own confusions, deeper than the social drama, though undeniably arising from it. Unlike any of the romantic and always frustrated scenes with Selden, the handsome prince, the scene of the attempted rape is the only one in the novel written in the rising and completed rhythms of sexual climax.

Contrasted with Lily's "freshness and slenderness" (77), Gus Trenor, sweaty, "red and massive" (77), with a "puffing face" cast in deep crimson by a match's glow, is her frog prince. (When a fairy-tale princess matures beyond her youthful fears of sexuality, she kisses the frog who is then revealed as a handsome prince; Lily, however, is unable to transcend her early repugnance to unite the two figures.) Lily's scenes with Selden are filled with throbbing and blushing. With Gus, these reactions are intensified, but in fear and anger. His resentful verbal attack makes her feel her "frightened heart throbs." "The words-the words were worse than the touch: Her heart was beating all over her body in her throat, her limbs, her helpless, useless hands" (142). "Trenor's face darkened to 
rage: her recoil of abhorrence had called out the primitive man." He comes closer "with a hand that grew formidable" (141-42). "She felt suddenly weak and defenseless: there was a throb of self-pity in her throat" (142). When he threatens her verbally "the brutality of the thrust gave her the sense of dizziness that follows on a physical blow" (141). "She flamed with anger and abasement." "Over and over her the sea of humiliation broke-wave crashing on wave. .." (143). When, at the last minute, Gus withdraws, "the sharp release from her fears restored Lily to immediate lucidity. The collapse of Trenor's will left her in control"' (144).

Although this is a scene of verbal confrontation whose explicit emotions are fear and anger, its imagery builds in a pattern of sexual tension and release. Its aftermath for Lily is severe shock. "All the while she shook with inward loathing. On the doorstep, . . . she felt a mad throb of liberation." But once outside and safe, "reaction came, and shuddering darkness closed on her" (144). Lily reacts with terrified dissociation: "She seemed a stranger to herself, or rather there were two selves in her, the one she had always known, and a new abhorrent being to which it found itself chained" (144). "There was a great gulf fixed between today and yesterday. Everything in the past seemed simple, natural, full of daylight - and she was alone in a place of darkness and pollution"' (145).

Although Lily is a creature of beauty and sensual charm, sexuality is not an acceptable part of her self-image. Responsibility is transferred to a male character; sexuality becomes Gus Trenor's domain, as hostility will be projected onto Bertha Dorset. The passionate imagery of fulfillment is therefore released from its pressurized control only in the context of brute force and coercion (in short, rape).

The brutality of Lily's encounter with Gus Trenor is complementary to the recurring frustration of her emotionally and physically unconsummated relation with Selden. Inhibited by the same fears that constrain Lily, Wharton has divided her characters in such a way that sexuality is isolated from both loving concern and romantic longing. The only male character who is realistic in his daily behavior and genuinely concerned about Lily is Simon Rosedale, whom she finds wholly unattractive. Structurally, Wharton suggests that Rosedale would be a proper mate for Lily and has named him accordingly. But she is ambivalent toward him. ${ }^{18}$ From the start, each encounter between Lily and Rosedale attempts a negotiation of intimacy, but since Lily is incapable of the closeness he

\footnotetext{
${ }^{18}$ Karl Miller, in "Edith Wharton's Secret," The New York Review of Books, 23 (Feb. 1978), makes this observation in a different context. As a dark, Jewish foreigner, he explains, Rosedale had the ambivalent attraction/repulsion of an outsider. Since his otherness made him socially unacceptable in Wharton's world as a love object, he could become the locus of disowned feelings of sexual attraction.
} 
offers, it remains unattractive to her. The first chapter of The House of Mirth begins with Lily's tête à tête with Selden and ends with her shunning Rosedale's proffered escort; this is the destructive movement of the novel as a whole.

While Selden, like the narrator, sees Lily through an aesthetic haze and simultaneously passes harsh moral judgments upon her, Rosedale understands her plainly and accepts her simply. $\mathrm{He}$ is the only man who is genuinely kind to Lily and the only one to tell her he loves her. Unlike any of the other voices in the novel, including the narrator's, Rosedale does not confuse the language of love and money, but talks of money when he means money, and love when he means love. Lily and Rosedale engage in honest dialogue and confrontation as Lily and Selden never do, but neither Lily nor the novel can accept familiarity because any intimacy is perceived as threatening. Rosedale's advances seem to Lily excessive, "intrusive," "odious"; they freeze her into repugnance (111). ${ }^{19}$

Selden and Rosedale are repeatedly juxtaposed in consecutive or reflecting scenes which should make Rosedale's virtues apparent but instead highlight Selden's appeal. Book I ends as Lily awaits Selden in her drawing room; Rosedale comes instead. Selden has deserted her; Rosedale offers marriage, but Lily feels such extreme disappointment over Selden's absence that Rosedale's presence is nothing but an irritation. When in Book II Lily walks with Rosedale, Wharton explicitly recalls her earlier golden September walk with Selden which evoked the soaring freedom of flight. In contrast, this November day "outlined the facts with a cold precision unmodified by shade or color, and refracted, as it were, from the blank walls of the surrounding limitations" (247). As she did with Gerty Farish, Wharton makes a life of practical action within accepted limitations seem intolerably harsh.

Considering that she might one day have to marry Rosedale, Lily feels that he stands for "one of the many hated possibilities hovering on the edge of life." Unlike Lily, or Selden, Rosedale operates from a real material base; he "set about with patient industry to form a background for his growing glory." "I generally have got what I wanted in life"' (172), he tells Lily. It is just the possibilities which make life possible that violate Lily's world of oceanic narcissism. As Gus Trenor was her frog prince, so Rosedale is her Rumplestiltskin, representing qualities she is unable to integrate within her own personality. An adult figure of autonomous in-

${ }^{19}$ Wharton's language makes Lily's revulsion quite physical and concrete: Lily shrinks "in every nerve from the way in which his look and tone made free of her" (252). She draws "away instinctively from his touch." When Rosedale's "smile grew increasingly intimate" (111), she withdraws with a "repugnance which kept her in frozen erectness." 
dustry, Rosedale shows the initiative and assertion that Lily fears and shuns-as she does him.

In the novel's only congenial scene of domestic "repose and stability" Wharton shows Rosedale with Carry Fisher's daughter, in a pose of "simple and kindly" "homely goodness" (243). But Lily is unable to decide whether this sight "mitigated her repugnance, or gave it, rather, a more concrete and intimate form" (244). When she considers Rosedale's offer of marriage, she cannot imagine further than her betrothal: "after that everything faded into a haze of material well-being . . . there were ... certain midnight images that must at any cost be exorcised-and one of these was the image of herself as Rosedale's wife"' (242-43).

No image of Lily as wife is possible in the imaginative world of this novel. Dividing essential qualities among disparate male characters, Wharton has not created a hero whom Lily might marry. But marriage is more than a literal solution for Lily and for the plot; it is a symbolic affirmation of maturity. Lily cannot marry because she is incapable of love. Both ability to love and the capacity for moral responsibility are predicated on the integration of sexual and active impulses. Wharton, however, rejects all assertive drives in symbolically coherent metaphors of pollution. In her Aunt Penniston's house, Lily resents the smell of wax and soap; she "behaved as though she thought a house ought to keep clean of itself, without extraneous assistance." Lily's encounters with the cleaning woman she here resents thread through the novel from beginning to end as moments of moral crisis. When Mrs. Haffen comes to Lily offering her letters with which to blackmail Bertha Dorset and restore her own good name, Lily shuns her offer with disdain, as she has earlier evaded her flood of soap suds. Wharton suggests that Lily's disgust and sense of contamination are noble, that her refraining is an act of moral courage (102). It is also, however, a refusal to get her hands dirty in taking practical action on her own behalf. Lily obscures the necessity of acting to promote her own needs or of acknowledging her potent desires for revenge; she maintains the idealized purity of her self-image at the ultimate cost of preserving her life.

The specific metaphor of dirt and cleanliness in which Lily's avoidance of adult responsibility is expressed recalls an oft-quoted reminiscence of Wharton herself, one which suggests a specific connection to childhood mothering. In her autobiographical A Backward Glance, Wharton tells of her first "novel," which began:

“' Oh, how do you do, Mrs. Brown?" said Mrs. Tompkins. "If only I had known you were going to call I should have tidied up the drawing-room.", Timourously I submitted this to my mother, and never shall I forget the sudden drop of creative 
frenzy when she returned it with the icy comment: "Drawing-rooms are always tidy." 20

C. G. Wolff's biography demonstrates that this anecdote is not anomalous, but typical of Wharton's impaired relation with her cold and demanding mother.

The array of mother figures in The House of Mirth also suggests a pervasive psychic configuration of inadequate maternal nurturance and support. Lily's troubles with sexual love and adult responsibility are symptomatic of a deeper problem. The key to Lily's relation with the male figures of the novel is in her relation to the female figures. The primary motivations that determine the plot of The House of Mirth are not actions with or among the men, but feelings of resentment and revenge among the women. Lily encounters a host of inadequate mother figures as she sinks from one to another down the social scale. Maternal intimacy suffers the same fate in this novel as sexual intimacy, and is in fact the model for it. The women who are concerned about Lily are made unattractive and powerless. Gerty Farish, truly generous and reliable, is persistently undercut by being made working-class, poor and drab, and a martyr who lacks sufficient sense of emotional preservation. When Carry Fisher is seen with her daughter in a maternal light, Lily finds her affection rather distasteful (as she does Rosedale's paternal pose in the same scene). Judy Trenor, an affectionate and giving friend at the start, is seen ultimately to be only a shallow, socially contingent creature who "could not sustain life except in a crowd" (38). ${ }^{21}$

While Lily's good mother figures are only ambivalently good and tend towards satiric caricature, the bad mothers are selfishly neglectful or powerfully destructive. Lily's Aunt Penniston, her official guardian whose home Lily finds ugly and impersonal, is caricatured with some of the vicious grotesquerie with which Flannery O'Connor images her potent and oppressive mother figures (cf. p. 32). In the money-for-love metaphor of this novel, Mrs. Penniston, the essence of female passivity and repression, gives her niece erratic gifts of money that encourage dependence, rather than the trust necessary for autonomy and self-regard (cf. p. 36). Influenced by Lily's poor cousin, Grace Stepney, the wronged and vengeful fairy-tale stepsister, Mrs. Penninston disinherits Lily. In the end, both love and money fail.

${ }^{20}$ Quoted by Wolff, A Feast of Words, 10, and Wilson, "Justice to Edith Wharton."

${ }^{21}$ Wharton accuses one of her characters of "woman like" accusing of the woman (158), and that is her own habit. Blame for the inadequacies of the whole socializing process is placed on the women who teach and enforce social paradigms. 
The woman whose actions are most immediately responsible for Lily's fate and for the mechanical workings of the novel's plot is Bertha Dorset. Just as Gus Trenor was made the villain of disowned sexuality, so Bertha becomes a malevolent presence, allowing Lily to be seen as the innocent victim of her manipulations and desires. The only fully enfranchised adult woman in the novel, Bertha is active, sexual, rich, powerful-and ruthlessly evil. She is made as vicious as the wicked stepmother of fairy tales, the cruel being created from the projected hostility of a child's resentment at wrongs done and love not given, from fears of retaliation for forbidden wishes. Like the feminine figure of projected evil in romances of male development, as long as she cannot be owned and reintegrated, her existence conceptually impedes the heroine's maturation.

While Wharton describes "an unavowed hostility" and a "thirst for retaliation" (116-17) between the two women, she attributes them not to Lily but to Bertha. Bertha first sabotages Lily's designs on Gryce, out of envy of Lily's relation with Selden (who has been Bertha's lover); finally Bertha camouflages a real love affair of her own by implying that Lily is having an affair with her husband. In a brilliant scene in a restaurant, Bertha ruthlessly destroys Lily's reputation by exposing her to public humiliation. The metaphors of Lily's encounters with Bertha are of battles in which words are weapons, weapons that "could flay [their] victims without the shedding of blood," and Bertha is "unscrupulous in fighting for herself"' (207).

This triangle with the Dorsets is a variant of the earlier scenario with the Trenors. In both, by a series of thin coincidences of bad luck and bad timing, Lily is observed in what seem to be sexually compromising situations. Her reputation is polluted; the resulting social ostracism indirectly causes her death. Unconvincing as literal plot, these scenes are rather unexamined Oedipal fantasies which both project responsibility onto the powerful figures of Gus or Bertha, and simultaneously punish Lily for specious guilt. The unresolved Oedipal triangle, however, is a more specific symbol of the pervasive psychic configuration of this novel's world: where inadequate nurturance and support lead to undeveloped self-esteem and a consequent inability to love or to work, the heroine remains fixed in passive dependency and the hungers of the unnurtured childhood state. The mode of primary narcissism remains her dominant emotional style.

The erratic giving and withholding of maternal affection or support is reflected by Lily's male lovers. Selden, especially, is critical and judgmental; he lets her down whenever she needs him most. Yet Lily is compelled to seek in the global fantasies of romantic love, of which he is the focus, a regressive mother-love of total acceptance and nurturance. 
The language of dark and hollow craving that surfaces repeatedly in the latter parts of the book reveals the extent to which Lily is controlled by the pervasive childlike neediness that is the underside of her narcissistic ecstasy. With no home, "no heart to lean on" (145) in moments of crisis, craving "the darkness made by enfolding arms" (145), Lily runs to Gerty Farish in "the open misery of a child" (162), and Gerty holds her "as a mother makes a nest for a tossing child" (164).

The scenes in which Wharton attempts to restore Lily to a nurturing relationship do not work. When Lily visits the working girl Nettie Struther and her infant, Wharton tries to use Nettie's good marriage and the baby, who reappears in Lily's fantasies as she drifts into the dream of her ambiguous suicide, to suggest the transcendence of the need for mothering in becoming a mother and experiencing nurturing feelings for a new infant. But the scene is drawn from fiction's stock, not from the novel's deeper sensibilities. The retreat to conventional devices is only a fragile aesthetic response which cannot match or resolve the resilience, richness, and provocativeness of her earlier evocations of positive narcissistic feelings. (By contrast, in a similar scene in Jane Eyre, Brontë recognizes both the anger at deprivation and the need for self-nurture and so is able to conclude her novel in a more realistic, if violent, emotional rhythm.) Wharton's narrative strategy, however, never integrates needs or angers in personality or in plot. Her heroine's hidden anger turns inward in selfdestruction, but even this dynamic is unclear for Wharton, whose handling of it is more sentimental than cathartic. Deprivation and anger remain undercurrents pulling beneath the plot; unacknowledged, they undermine the structure in which Wharton tries to confine them.

In The House of Mirth Wharton transforms a personal psychic despair into a pessimistic social determinism, locating in society the forces of inevitable destruction of spirit that proceed from within. Ultimately, of course, there is a reciprocal relation between psyche and society. The narrative sensibility that creates the social world of this novel is itself shaped by development in society. Wharton shows Lily's destruction by the contradictions and limitations of needing to be independent and adult in a social context that neither equips nor permits her to be. In this, Lily, like many other heroines, acts out a cultural dilemma: when society provides no adult female role of active responsibility and initiative, women are confined to passive and childlike states and cannot mature.

Within the psychic structure of Wharton's fiction, Lily's destruction is determined. Her undoing is implicit in the very illumination of her initial descriptions; what attracts us most to her is what dooms her. Reading the novel in this psychological mode is not to deny the destructive effect of 
social arrangements on women's development, but rather more fully to demonstrate it. The ultimate locus of damage by inadequate social structures is within the individual. The internal arena of the author's sensibility becomes the demonstration ground of the social harms she criticizes; and the flawed structure of her novel, as much as her heroine's death, shows the debilitating effects of the constrictions on realistic self-assertion. Wharton's statement about the destructiveness of her limited social world is ultimately strikingly successful, only more indirect than she may have intended.

Wolff's biography suggests that the unresolved narcissism of the world of The House of Mirth parallels Wharton's own delayed emotional maturation. Wharton had not resolved the dilemma of integrating sexuality and assertiveness when she wrote this novel. "Every one of the early fictions," writes Wolff, "had been devoid of genuine adult passion. . . . The terms in which Wharton experienced sexual passion were indelibly colored by the fearful shades of an earlier, more primitive, and more inclusive hunger. . . . a threatening resurgence of that infantile sense of unsatisfied, insatiable oral longing" connected with earlier problems with maternal love. ${ }^{22}$ In this context we can understand differently Wharton's determinism. Tied by excessive fears about the destructive powers of assertive passions, Wharton was unable to free herself from believing in the necessary control of the strict code of manners of the society whose rigid constraints on the human spirit she so pointedly criticized.

Lily has to die because she cannot live. A grown and beautiful woman, she can no longer exist as a child, but neither can she become an adult. We feel the pull of human character in Lily, a growing sympathy and self-knowledge, but society cannot support her development. All her romance "helpers" fail her. Her evil mother figures have more power to hurt than the good ones do to help. She has only a defective Prince Charming who has the magical power to change her complacent vision of the world, but is unable to transport her to a kingdom beyond. The House of Mirth is both a failed romance of identity and a romance of failed identity. It ends not with wisdom, integrity, and social reintegration, but with regression to infancy and death (like many female bildungsromane). Not only does Lily fail in her attempts at growth and self-sufficiency, but Wharton too fails to create a sustained aesthetic structure to legitimate the integrity of her struggle. She is able to make her heroine noble only as a suffering victim; she cannot create a responsible adult of moral dimensions-a tragic heroine. In her inability to image woman's responsibility for herself, Wharton shares a larger cultural tradition. Lily's stock

${ }^{22}$ Wolff, A Feast of Words, 191, 206. 
death acts out the social prohibitions that deny women active maturity (as well as the punitive judgment that blames victims for their victimization). Wharton writes within a central tradition of American thought that manifests itself in literature in the favored use of the polarizing, simplistic form of romance.

Still, something of considerable power is going on in this fiction. In The House of Mirth, Wharton is able to tap the well of childhood narcissism and use those resonant feelings to create a brilliantly memorable character. While others of Wharton's novels have a more perfectly balanced structure, Lily's fire appeals directly to those sustained remnants of narcissism in adults. Like a child or a lover, she speaks to our capacity for narcissistic projection; the strength of our response to her derives from the potency of those feelings in us. The historical mythology of romantic love testifies to the intensity of suppressed and withheld passions; thwarted feeling paradoxically heightens aesthetic effects. As we are charmed by doomed lovers and by dreams of Eden-with all their permanent remoteness in time and place, their nostalgia of impossibility and loss-so we are charmed by Lily Bart. She is able to find in her readers' hearts the place she could never find in her world. In fiction's own magical transformation of constriction to transcendence, the repression of sexual and active energy becomes the potent pressurizing force that forges the lasting power of Lily's appeal. 